\title{
Population dynamics of three commercially important bivalve species (Family: Veneridae) in Puttalam lagoon and Dutch bay, Sri Lanka
}

\author{
H.M.P. KITHSIRI ${ }^{1 *}$, M.J.S. WIJEYARATNE ${ }^{2}$ AND U.S. \\ AMARASINGHE ${ }^{2}$ \\ ${ }^{1}$ National Aquatic Resources Research and Development Agency \\ Crow Island, Colombo 15, Sri Lanka \\ ${ }^{2}$ Department of Zoology, University of Kelaniya, Kelaniya, Sri Lanka \\ * Corresponding author: E-mail: palitha_kithsiri@hotmail.com
}

\begin{abstract}
The present study was carried out to investigate the population dynamics of three bivalve species, viz, Gafrarium tumidum, Marcia hiantina and Marcia opima in Dutch bay and Puttalam lagoon, Sri Lanka, in order to make recommendations for sustainable exploitation of these resources. The growth performance index $\left(\emptyset^{\prime}\right)$ for the three species calculated from asymptotic length and growth constant, which were estimated using Compleat ELEFAN software package, ranged from 3.19 to 3.48 in Dutch bay and from 3.18 to 3.40 in Puttalam lagoon. The slightly better growth performance in Dutch bay may be due to more favourable environmental conditions than in Puttalam lagoon.

In Dutch bay, $M$. hiantina and $M$. opima which were less abundant, were heavily exploited, as opposed to the most abundant $G$. tumidum, which was least exploited. Exploitation rates of $G$. tumidum, M. hiantina and $M$. opima were $0.30,0.83$, and 0.73 respectively. Two recruitment pulses occurred in the three bivalve populations in Puttalam lagoon while a single recruitment pulse occurred in Dutch bay. As such, the three bivalve populations in Puttalam lagoon appear to be " $r$ - selected" while those in Dutch bay appear to be " K- selected". This study revealed that the three bivalve species occurring in Dutch bay could support a small-scale fishery.
\end{abstract}


H.M.P. Kithsiri et al.

\section{Introduction}

The Puttalam-lagoon and Dutch bay form the largest brackish to saline water body in Sri Lanka and lies within the Puttalam district of the North Western province. It is located between longitudes $79^{\circ} 42^{\prime}-79^{\circ} 50^{\prime} \mathrm{E}$ and latitudes $7^{\circ} 55^{\prime}-8^{\circ} 32^{\prime} \mathrm{N}$ (Fig. 1).

Bivalve resources are reported to be abundant in the coastal waters of Sri Lanka. Although bivalves are not particularly popular among Sri Lankans, increasing numbers of fishing families who are involved in deep sea fisheries, harvest bivalves during the monsoon seasons and also during peak tourist seasons (Lovatelli 1988). Most of the bivalves in Sri Lanka are collected for lime production (Fernando 1977).

The distribution of three species of bivalves viz, Gafrarium tumidum, Marcia hiantina and Marcia opima and the influence of salinity, seagrass coverage, organic matter content of soil and soil texture on their abundance in Puttalam lagoon and Dutch bay have been studied by Kithsiri et al. (2000). However, no published information is available on the population parameters and the level of sustainable exploitation of these resources in Sri Lanka. The present study was therefore, carried out to investigate the population dynamics of these three bivalve species in Dutch bay and Puttalam lagoon, in order to make recommendations for their sustainable exploitation.

\section{Materials and Methods}

This study was carried out for a period of 2 years from September 1991 to August 1993 in fifteen sampling sites in Puttalam lagoon and Dutch bay (Fig. 1). The area of each sampling site was approximately $100 \mathrm{~m}^{2}$. Sampling was carried out once a month in each sampling site. On each sampling day a metal quadrate of $1 \mathrm{~m}^{2}$ in area was placed randomly in each site and the bivalves dwelling on the soil surface were collected. Bivalves within the soil were collected by digging up soil within the quadrate down to a depth of $10 \mathrm{~cm}$. Bivalves were separated by wet sieving through $3 \mathrm{~mm}$ plastic mesh. The relative abundance of bivalves at each sampling site was estimated using the data collected from five quadrate samples.

In the laboratory, the bivalves were identified using the characteristics described by Fernando (1977). The shell length of each individual was measured to the nearest $1 \mathrm{~mm}$ using a vernier caliper. Length frequency data of $G$. tumidum, $M$. hiantina and $M$. opima collected by quadrate sampling were analyzed separately for Puttalam lagoon and Dutch bay using the Compleat ELEFAN version 1.1 software package (Gayanilo and Pauly 1989, Gayanilo et al. 1989). 
Population dynamics of three bivalve species

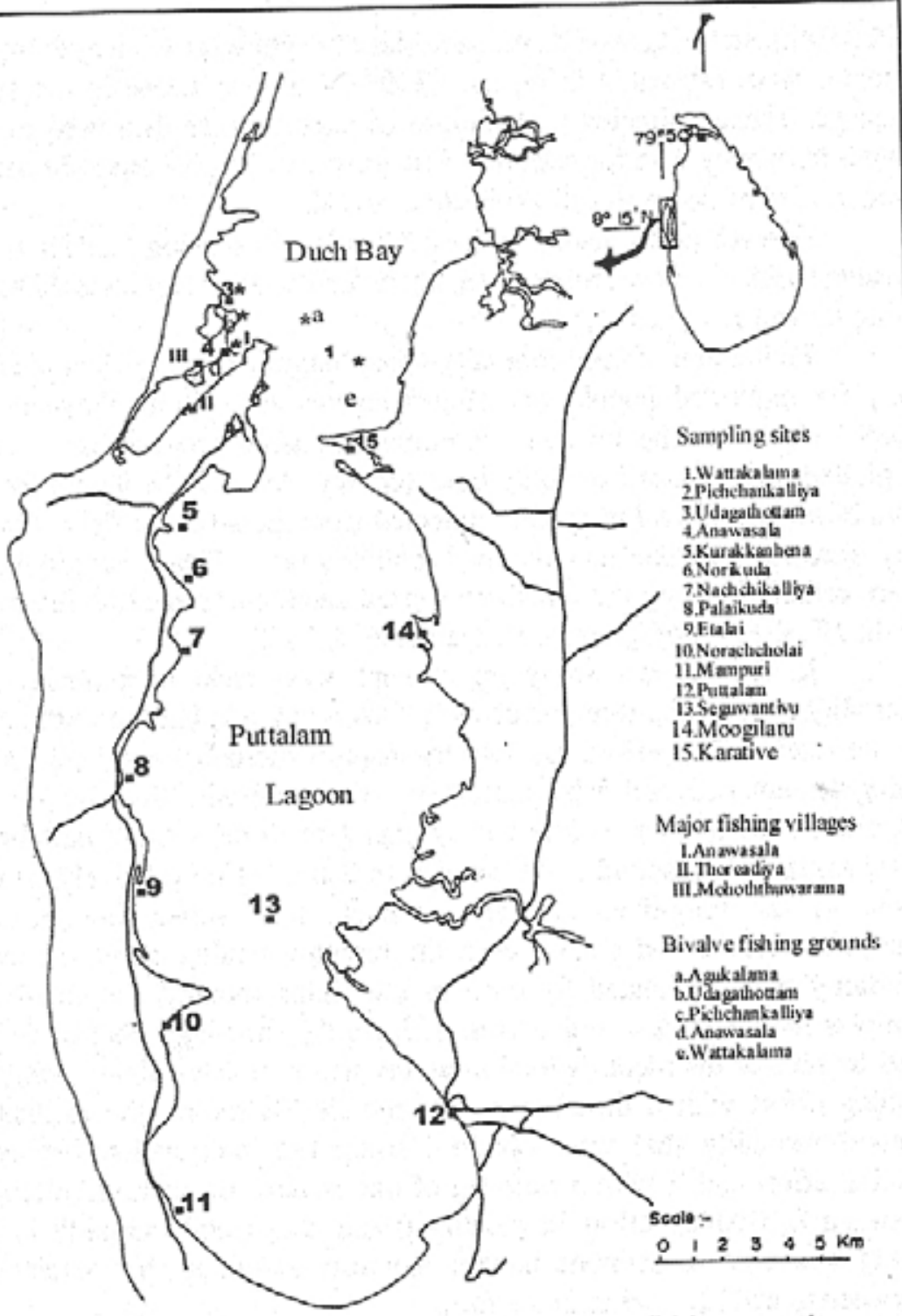

Fig.1 Sampling sites, major fishing villages and major fish ing grounds

Step-wise procedure described by Amarasinghe and De Silva (1992) was adopted in this analysis. Accordingly, an initial estimate for asymptotic length $\left(\mathrm{L}_{\infty}\right)$ was obtained using the rule of thumb $\left(\mathrm{L}_{\infty} \approx \mathrm{L}_{\max } / 0.95\right)$, (Pauly 1981) where $L_{\max }$ is the maximum recorded length. Using this value as an initial $\mathrm{L}_{\infty}$ value, $\mathrm{K}$ was estimated for each bivalve species using ELEFAN I programme based on $5 \mathrm{~mm}$ class intervals of length frequencies. Using the 
initial estimates of $\mathrm{L}_{\infty}$ and $\mathrm{K}$, probabilities of capture for the length frequency samples were estimated using the ELEFAN II programme in the software package. These estimated probabilities of capture were then used to correct length frequency data for selection and corrected length frequency data were used to obtain improved estimates of $\mathrm{L}_{\infty}$ and $\mathrm{K}$.

Growth performance indices $\left(\varnothing^{\prime}=\log \mathrm{K}+2 \log \mathrm{L}_{\infty}\right)$ for the three bivalve species were calculated separately for Puttalam lagoon and Dutch bay using $\mathrm{L}_{\infty}$ and $\mathrm{K}$ values.

Estimation of total mortality using length frequency data is effective only for exploited populations (Beverton and Holt 1956; Gayanilo et al. 1989). However, the bivalves in Puttalam lagoon are not exploited. The exploited populations exist only in Dutch bay. As such the length frequency data of the three bivalve species collected from the artisanal fishery in Dutch bay were used to determine the total mortality rates. Total mortality rates (Z) were estimated using the length-converted catch curve method incorporated in the ELEFAN II programme (Gayanilo et al. 1989).

In the present study an attempt was made to estimate natural mortality rates of the three bivalves in Dutch bay relating the total mortality to the total fishing effort. Usually the natural mortality rates are estimated using the data of $\mathrm{Z}$ and fishing effort on an annual basis. Since these bivalves are short-lived species with relatively high growth rates, total mortality rates were assumed to respond to the changes in fishing effort relatively faster than those of the long-lived species. As such, time series cross-correlation analyses were carried out between the monthly fishing effort ( $f$ ) and total mortality rates calculated for each month taking monthly length frequency samples individually in order to investigate the time-lag effect of $f$ on $Z$. It was found that the monthly total mortality was correlated significantly to the fishing effort with a time-lag of one month. Therefore, the estimates for natural mortality $(M)$ were obtained using the interrelation between the fishing effort and $Z$ with a time-lag of one month. As such the relationship between $\mathrm{f}_{\mathrm{m}}$ (fishing effort in month $\mathrm{m}$ ) and $\mathrm{Z}_{\mathrm{m}+1}$ (total mortality in month $\mathrm{m}+1$ ) was used to estimate natural mortality assuming that a relationship between $f_{m}$ and $Z_{m+1}$ exists in the form

$$
Z_{m+1}=M+q f_{m}
$$

where $\mathrm{M}$ is natural mortality and $\mathrm{q}$ is a constant. Fishing mortality rates for the three bivalve species in Dutch bay were then estimated by subtracting $M$ from Z.

Probabilities of capture for different length classes of bivalves were estimated by backward projection of the catch curves. These estimated probabilities of capture of different length classes were plotted against their corresponding mid-lengths and the selection curves were obtained. Mean 
sizes at first capture i.e., sizes at $50 \%$ retention for the three species were estimated from these selection curves. Probabilities of capture for different size classes were estimated for 1992 and 1993 separately, and for the 2 years combined. The latter was performed to estimate the overall mean size at first capture $(\mathrm{Lc}$ ) because the $\mathrm{Lc}$ values did not change appreciably from 1992 to 1993.

The recruitment patterns of the three bivalve species were derived by the ELEFAN II programme. The annual recruitment pattern was obtained by backward projection of the monthly length frequencies on to one year time axis (Gayanilo et al. 1989).

Using the Compleat ELEFAN package (Gayanilo et al. 1989), relative yield per recruit values at different exploitation rates $(\mathrm{F} / \mathrm{Z})$ were estimated for 5 different sizes at first capture $(\mathrm{Lc})$ incorporating their corresponding selection patterns according to the method described by Pauly and Soriano (1986).

\section{Results}

Since Von Bertalanffy growth formula (VBGF) is said to be valid for mathematical description of observed growth (Moreau 1987), it was used in the present study to describe the growth of bivalves in Puttalam lagoon and Dutch Bay. Restructured and percentage length frequency data with superimposed growth curves for the three bivalve species in Puttalam lagoon and Dutch Bay are given in Figs 2-7.

The estimated values for asymptotic length $\left(\mathrm{L}_{\infty}\right)$ and growth constant (K) are given in Table 1. For all these species the values for $\mathrm{K}$ were higher and the $\mathrm{L}_{\infty}$ values were lower in Puttalam lagoon than in Dutch bay indicating an accelerated growth in the lagoon.

Table 1. Growth parameter estimates for the three bivalve species in Puttalam lagoon and Dutch bay (P.L.= Puttalam Lagoon; D.B.= Dutch Bay).

\begin{tabular}{lllllll}
\hline \multirow{2}{*}{ Parameter } & \multicolumn{2}{c}{ G. tumidum } & \multicolumn{2}{c}{ M. hiantina } & \multicolumn{2}{c}{ M. opima } \\
\cline { 2 - 7 } & P.L. & D.B. & P.L. & D.B. & P.L. & D.B. \\
\hline Asymptotic length (mm) & 55.6 & 63.6 & 47.8 & 53.9 & 46.8 & 48.7 \\
Growth constant (1/yr) & 0.82 & 0.74 & 1.11 & 0.90 & 0.71 & 0.65 \\
$\begin{array}{l}\text { Growth performance } \\
\text { index (Ø') }\end{array}$ & 3.40 & 3.48 & 3.40 & 3.42 & 3.18 & 3.19 \\
\hline
\end{tabular}


H.M.P. Kithsiri et al.

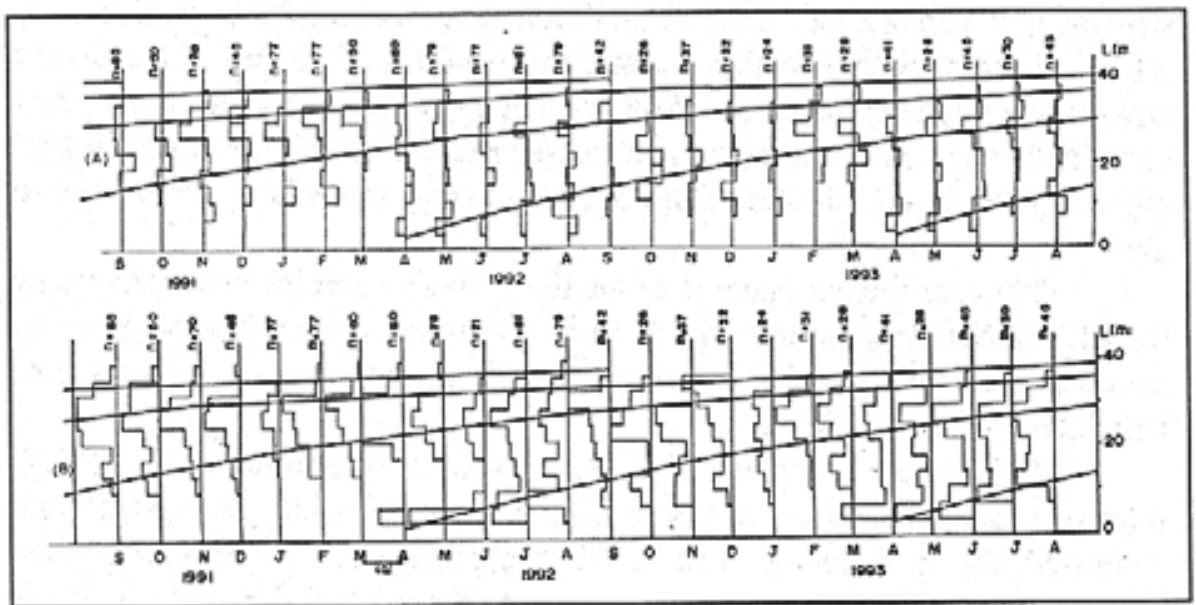

Figure 2. Restructured and percentage length frequency data and superimposed growth curves for G. tumidum in Puttalam lagoon ( $\mathrm{n}=$ number of bivalves measured in each month). A - Restructured length frequency data; B - Percentage length frequency data.

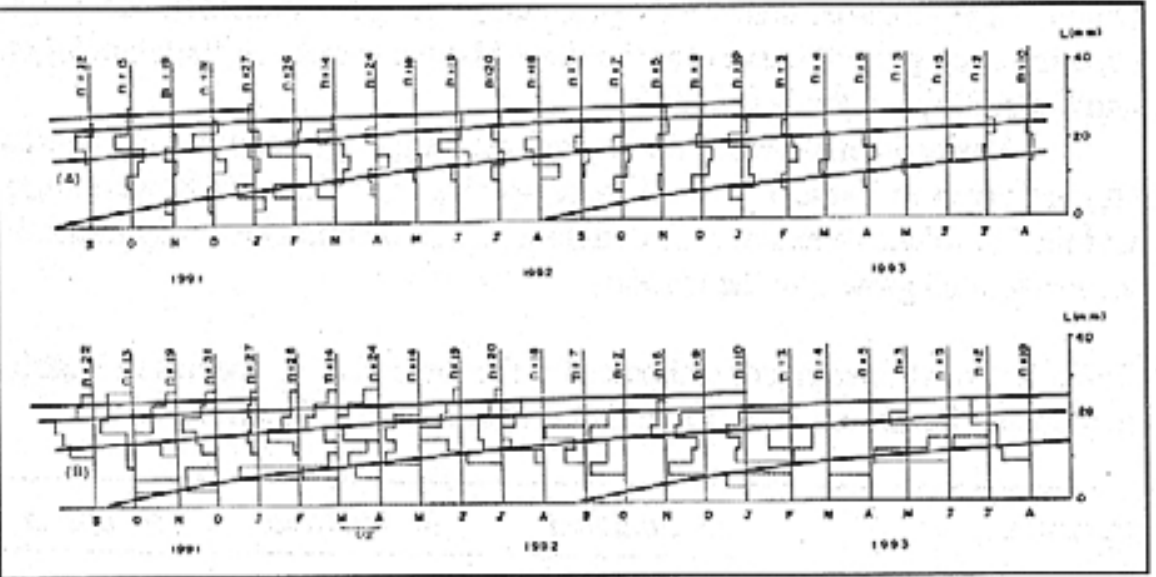

Figure 3. Restructured and percentage length frequency data and superimposed growth curves for $M$. hiantina in Puttalum lagoon ( $\mathrm{n}=$ number of bivalves measured in each month). A - Restructured length frequency data; B - Percentage length frequency data. 
Population dynamics of three bivalve species

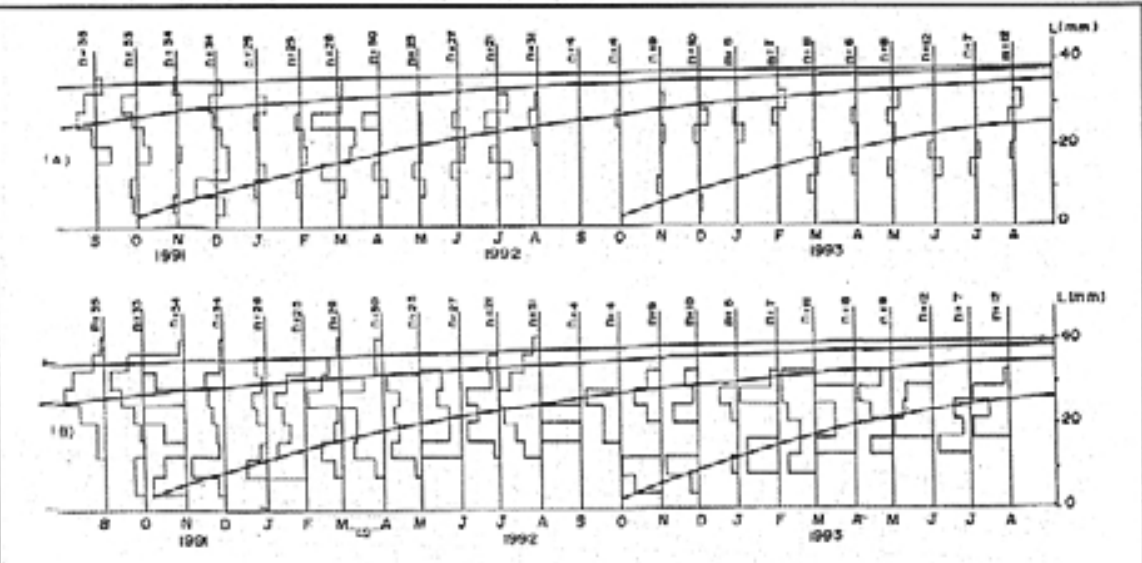

Figure 4. Restructured and percentage length frequency data and superimposed growth curves for $M$. opima in Puttalam lagoon $(\mathrm{n}=$ number of bivalves measured in each month). A - Restructured length frequency data; $\mathrm{B}$ - Percentage length frequency data.

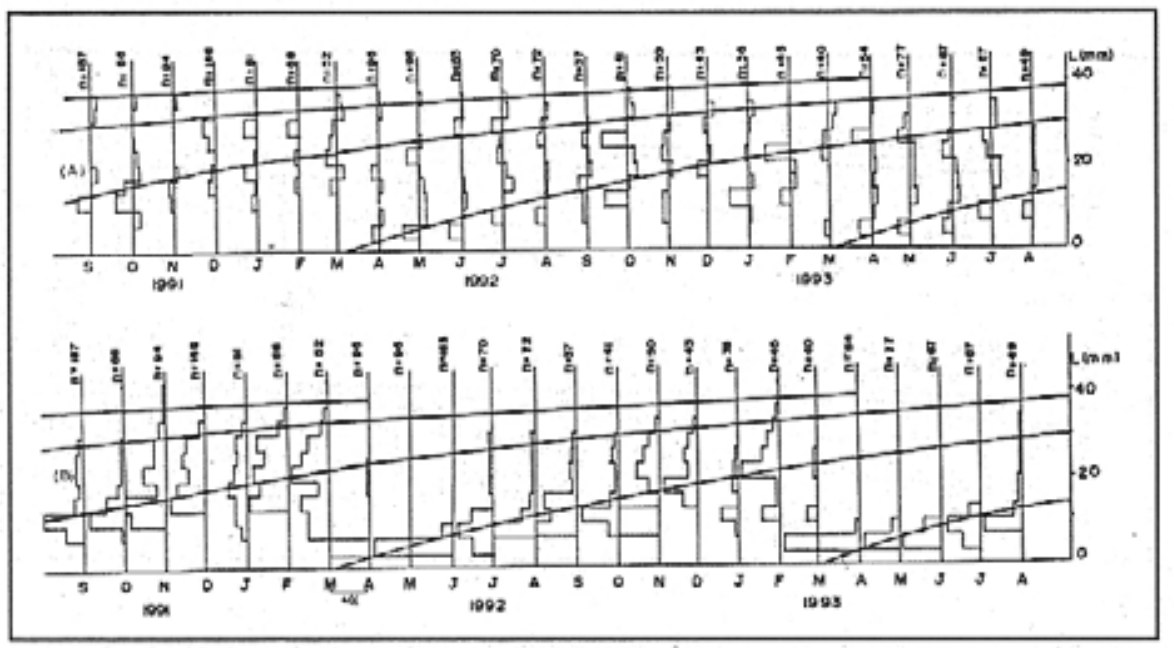

Figure 5. Restructured and percentage length frequency data and superimposed growth curves for $G$. tumidum in Dutch bay ( $\mathrm{n}=$ number of bivalves measured in each month). A - Restructured length frequency data; B - Percentage length frequency data 
H.M.P. Kithsiri et al.

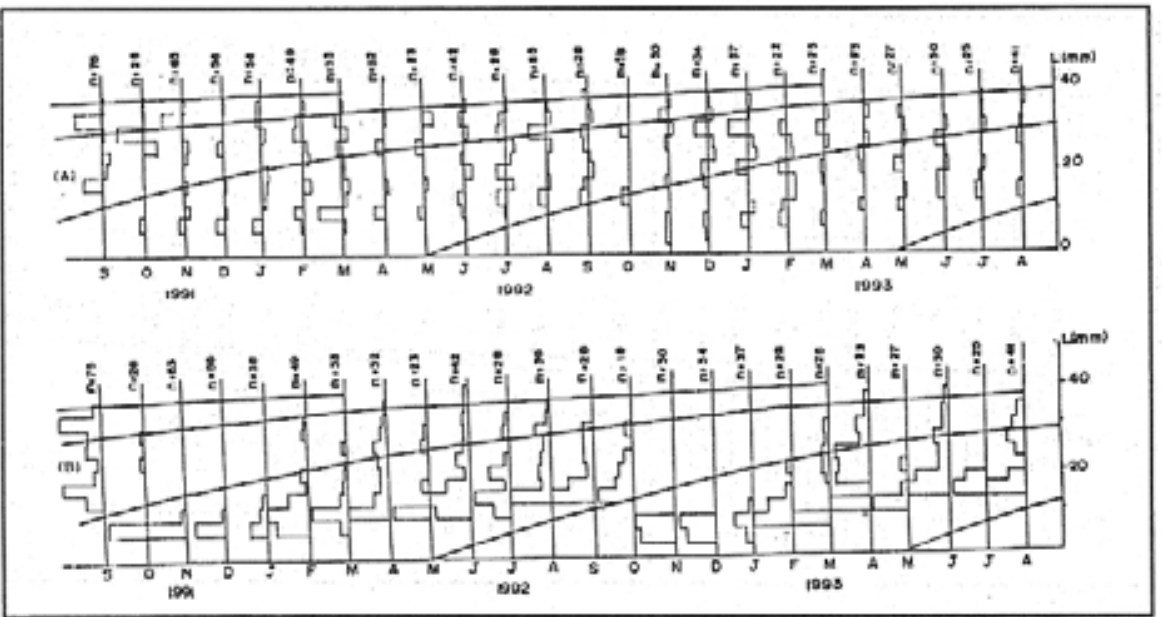

Figure 6. Restructured and percentage length frequency data and superimposed growth curves for $M$. hiantina in Dutch bay ( $\mathrm{n}=$ number of bivalves measured in each month). A - Restructured length frequency data; B - Percentage length frequency data

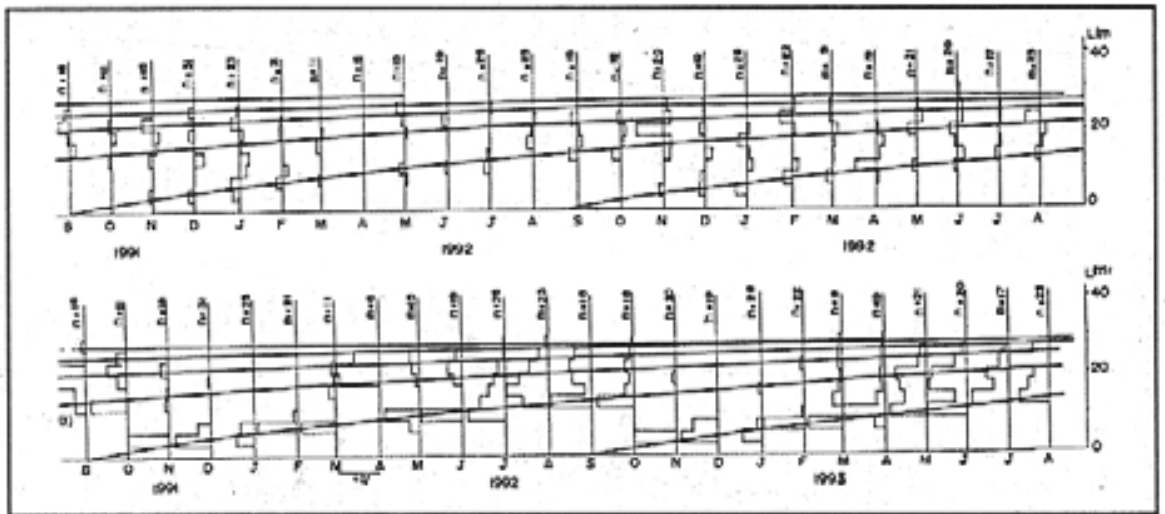

Figure 7. Restructured and percentage length frequency data and superimposed growth curves for M. opima in Dutch bay ( $\mathrm{n}=$ number of bivalves measured in each month). A - Restructured length frequency data; B - Percentage length frequency data 


\section{Population dynamics of three bivalve species}

Table 2. Estimates for mortality rates, exploitation rates (E), and sizes of first capture (Lc) of $G$. tumidum, $M$. hiantina and $M$. opima in Dutch bay. ( $\mathrm{Z}=$ total mortality rate; $\mathrm{M}=$ natural mortality rate; $\mathrm{F}=$ Fishing mortality rate).

\begin{tabular}{llllll}
\hline Species & $\begin{array}{l}\mathrm{Z} \\
\left(\mathrm{yr}^{-1}\right)\end{array}$ & $\begin{array}{l}\mathrm{M} \\
\left(\mathrm{yr}^{-1}\right)\end{array}$ & $\begin{array}{l}\mathrm{F} \\
\left(\mathrm{yr}^{-1}\right)\end{array}$ & $\mathrm{E}$ & $\begin{array}{l}\mathrm{Lc}(\mathrm{mm}) \\
92 / 93\end{array}$ \\
\hline G. tumidum & 4.13 & 2.91 & 1.22 & 0.304 & 36.3 \\
M. hiantina & 3.23 & 0.52 & 2.71 & 0.882 & 33.3 \\
M. opima & 1.54 & 0.23 & 1.31 & 0.773 & 31.9 \\
\hline
\end{tabular}

The growth performance indices for the three bivalve species are also given in Table 1. These values for the three species were higher in Dutch Bay than in Puttalam lagoon.

The estimated values for total mortality coefficient $(Z)$ for all three species in the Dutch bay are given in Table 2. Since the annual $\mathrm{Z}$ value for 1992 and 1993 were approximately close to each other, the mean annual $Z$ for 1992/1993 were used in subsequent analysis. .

The correlation coefficients between the monthly values for $\mathrm{Z}$ and fishing effort (f) for these three bivalve species in Dutch bay with different time-lags are shown in Fig. 8. The results indicated that total mortality of the three bivalve species is more significantly influenced by fishing effort with a time-lag of one month.

The values for natural mortality coefficient $(M)$ thus estimated are given in Table 2. The highest value for $\mathrm{M}$ was estimated for $G$. tumidum while the lowest was estimated for $M$. opima. Fishing mortality rates for the three bivalve species in Dutch bay are also given in Table 2 . The fishing mortality coefficient of $M$. hiantina was very much higher than those of $G$. tumidum and $M$. opima.

Exploitation rates $(E)$ for the three bivalve species are also given in Table 2. The exploitation rates of $M$. hiantina and $M$. opima were higher than that of G. tumidum.

Probabilities of capture for the three bivalve species in Dutch Bay are shown in Fig. 9. Mean size at first capture i.e., the size at 50\% retention (Lc) estimated from these selection curves for the three species for 1992/1993 is also given in Table 2. This was performed to estimate the overall mean size at first capture (Lc), because the Lc values do not change appreciably from 1992 to 1993.

The recruitment patterns of G. tumidum, M. hiantina, and M. opima in Puttalam lagoon and Dutch bay are shown in Figs 10 and 11 respectively. Recruitment pattern of each of these three bivalve species in Dutch bay 
shows a single peak whereas in Puttalam lagoon it shows two peaks of unequal strengths.

The relative yield per recruit (Y/R) values as functions of exploitation rates for G. tumidum, M. hiantina and M. opima for different Lc values are shown in Fig. 12. The present levels of exploitation rates for these three bivalve species are also shown in these figures. For $G$. tumidum, the maximum relative $\mathrm{Y} / \mathrm{R}$ is obtained at a exploitation rate $(\mathrm{E})$ of around 0.6. However, the present $\mathrm{E}$ is 0.3. Therefore, it appears that for this species, $\mathrm{E}$ can be further increased. However, for the other 2 species, the present levels of $\mathrm{E}$ are slightly higher than the exploitation rate which gives the maximum Y/R. Therefore, by reducing the present $\mathrm{E}$ slightly the present yield could possibly be increased.

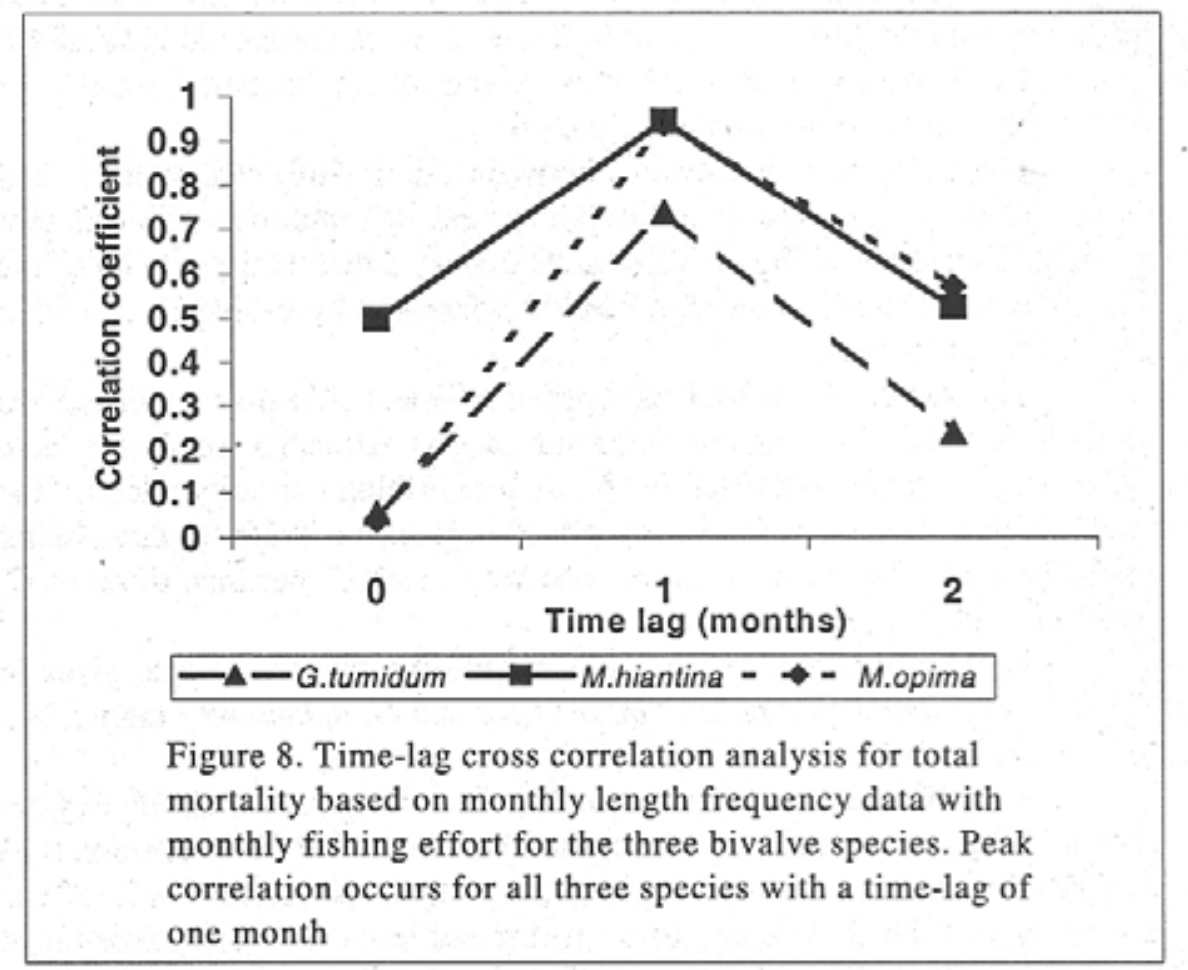


Population dynamics of three bivalve species

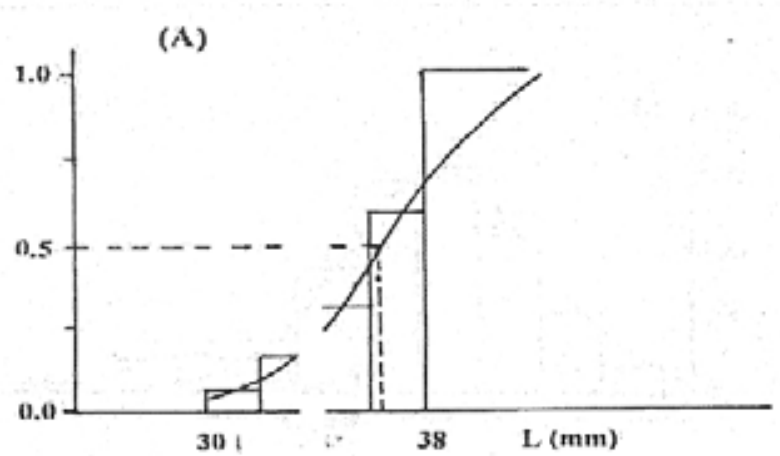

(B)
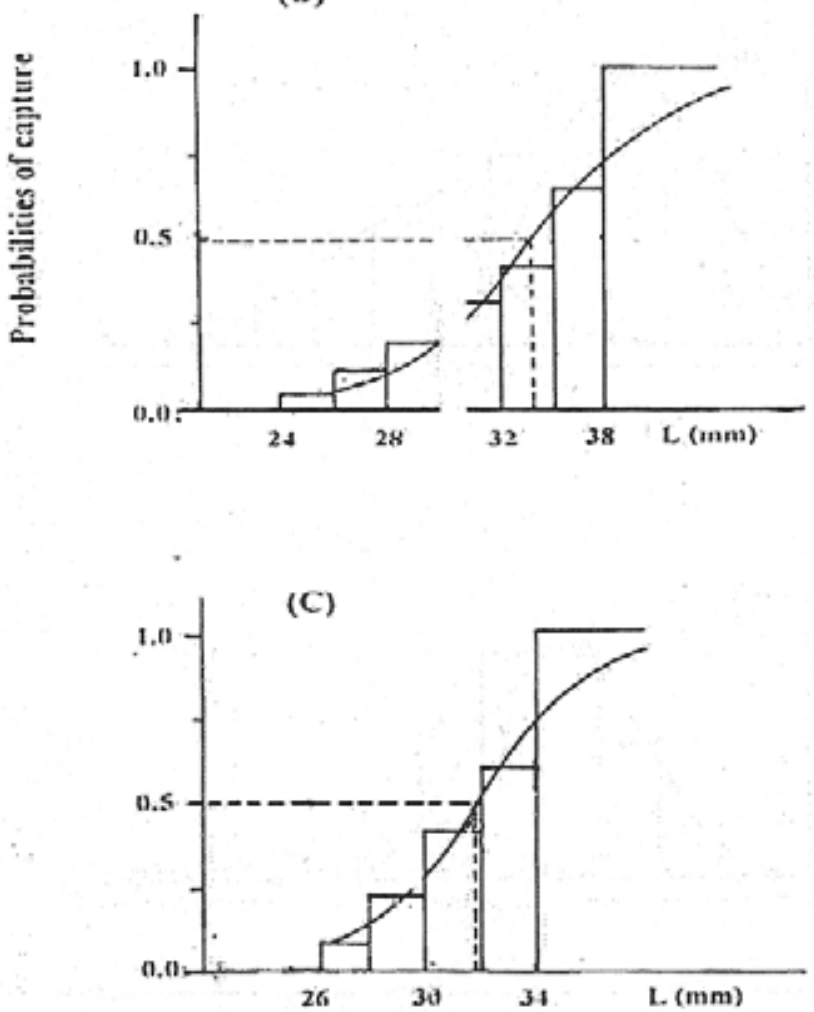

Figure 9. Selection curves for G. tumidum (A); M. hiantina (B); and $M$. $\operatorname{opima}(\mathrm{C})$ in Dutch bay. 

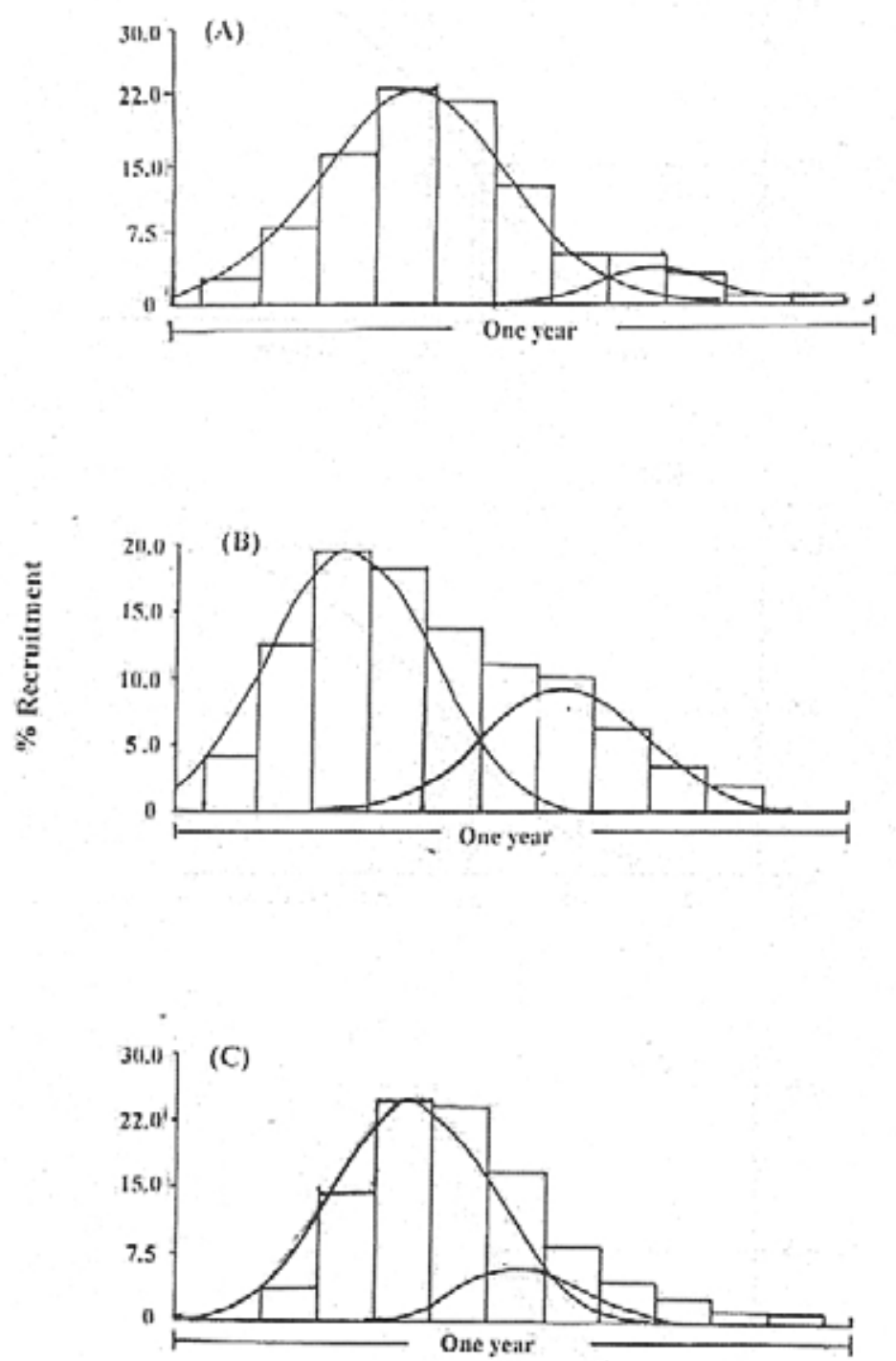

Figure 10. Recruitment patterns for G. tumidum (A); M. hiantina (B); and M.opima (C) in Puttalam lagoon. 
Population dynamics of three bivalve species

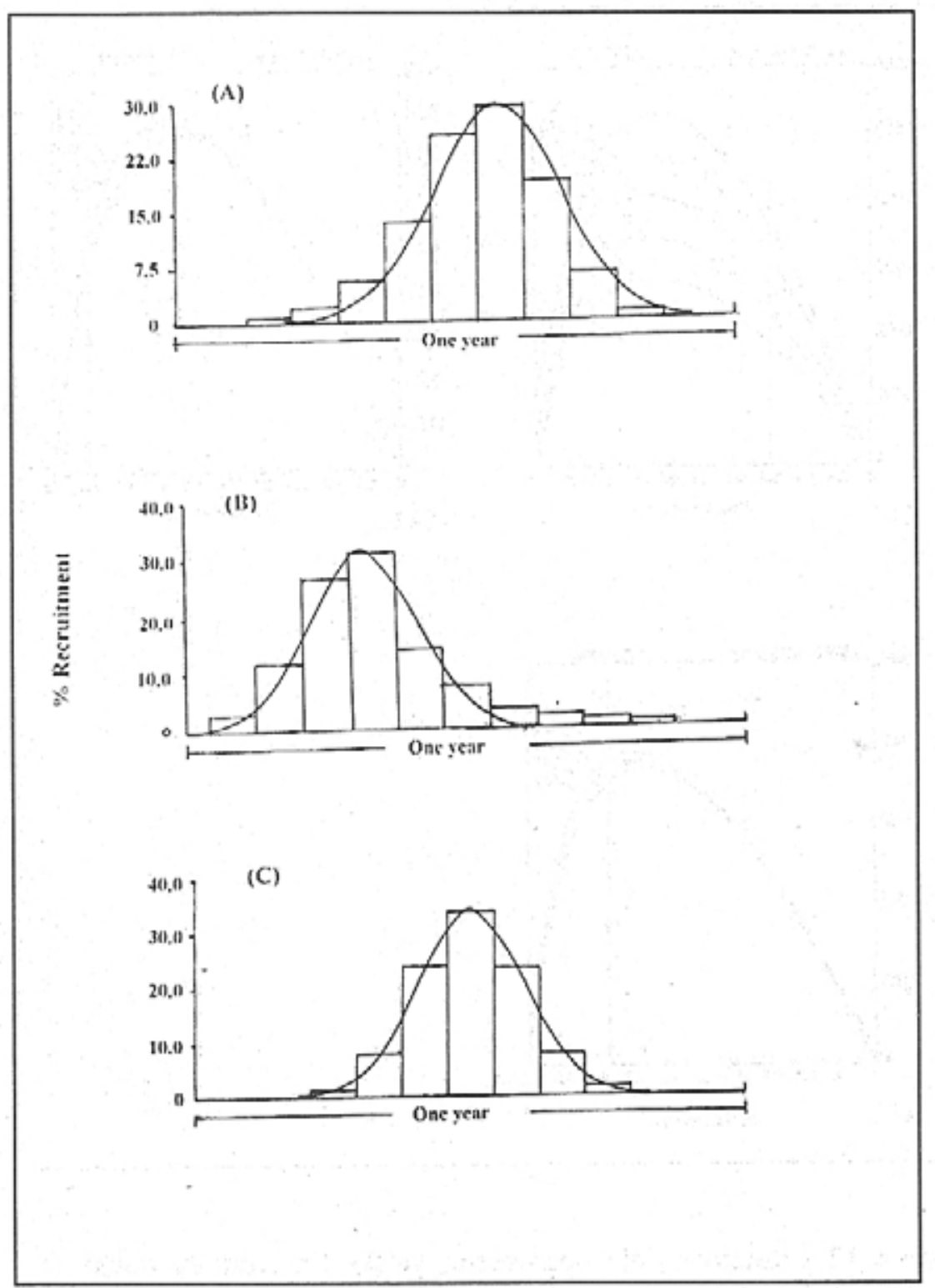

Figure 11. Recruitment patterns for G. tumidum (A); M. hiantina (B); and M.opima (C) in Dutch bay. 
H.M.P. Kithsiri et al.

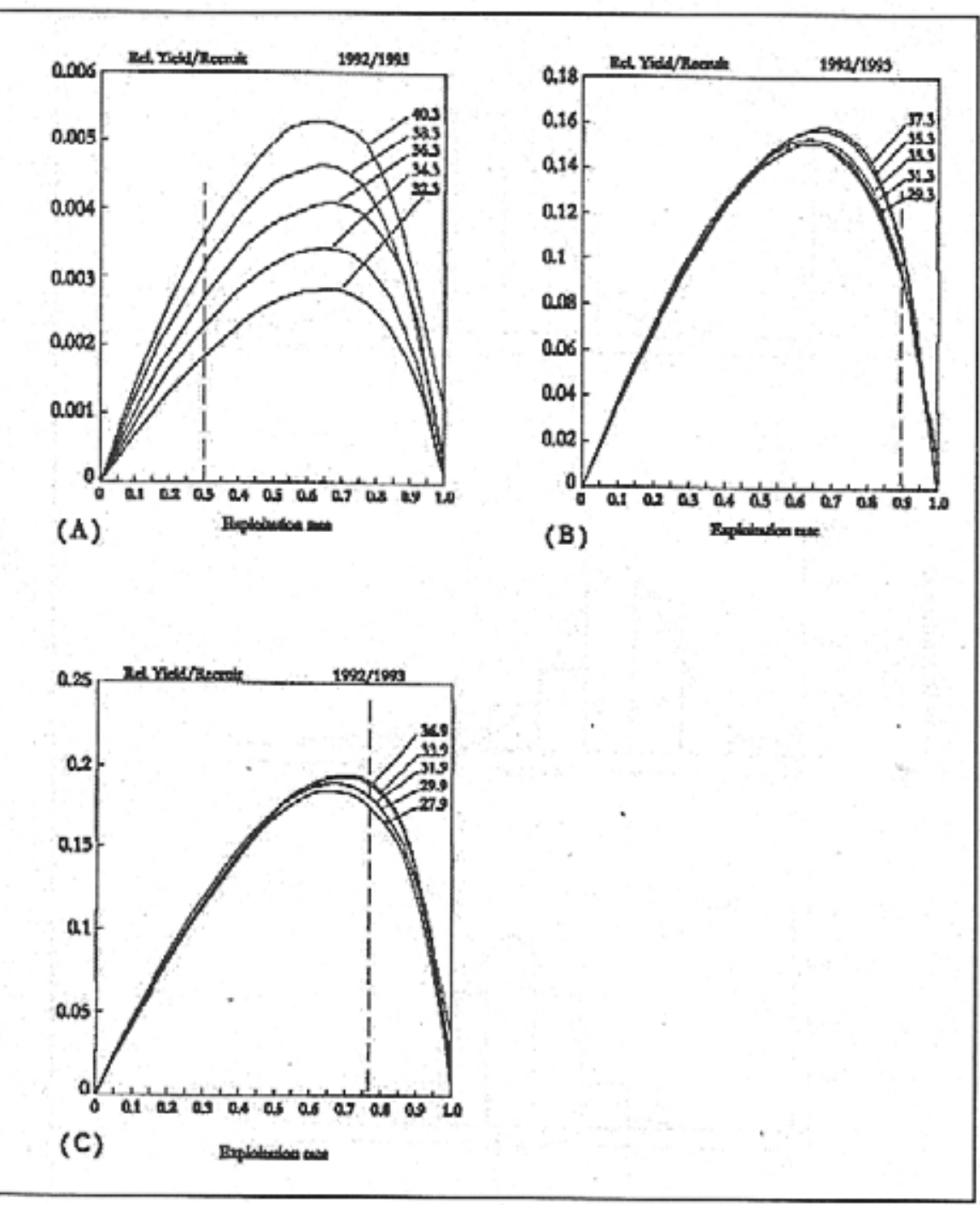

Figure 12. Relative yield -per-recruit values (in arbitrary units) as functions of exploitation rate for G. tumidum (A), M. hiantina (B) and, M. opima $(C)$ in Dutch bay. In each analysis, five curves were drawn for five different sizes $(\mathrm{mm})$ at first capture. The vertical broken lines indicate present levels of exploitation rates. 
Population dynamics of three bivalve species

\section{Discussion}

Since the fishery for bivalves is seasonal and only larger individuals are caught, use of length frequency data collected by sampling the catches of the artisanal fishery would not give an accurate estimation of growth parameters. Hence length data of the individuals collected by quadrate sampling, which contained smaller individuals too were used to study growth parameters.

The growth and mortality parameters of bivalves differ with the locality and species. This is mainly due to the differences in environmental conditions, densities of bivalves and their size distributions (Oon 1986). The differences in growth parameters of these three bivalve species in Puttalam lagoon and Dutch bay may also be due to the differences in environmental factors in these two areas. The populations of the three bivalve species in Puttalam lagoon have higher $\mathrm{K}$ and lower $\mathrm{L}_{\infty}$ values than those in Dutch bay. These differences in growth could be explained by the concept of $\mathrm{r}$ and $\mathrm{K}$ selection (Pianka 1970). The accelerated growth of these three bivalve species taking place in the Puttalam lagoon corresponds to " $r$-selected" life style which is brought about by relatively' unstable environmental conditions (Pianka 1970). The heavy fluctuations of salinity levels, unfavourable substrate characteristics and comparatively low mean depth at some sampling sites i.e., Nachchikalliya, Nurochcholei, Ethalai and Puttalam (Fig. 1) (Kithsiri et al. 2000) may be among the reasons for low $\mathrm{L}_{\infty}$ and high $\mathrm{K}$ values observed for the bivalve populations in Puttalam lagoon.

Low $\mathrm{K}$ and high $\mathrm{L}_{\infty}$ of the three bivalve species in Dutch bay area could be due to more favourable environmental conditions such as favourable salinitý levels, favourable sand/clay content of the substratum, high organic matrer content in the soil and high seagrass cover (Kithsiri et al. 2000) that help to bring about " $\mathrm{K}$ - selected" life style.

Oon (1986) found that the growth performance values of Anadara granvsa differ when exposed to different environmental conditions. The grc $\hat{w}$ th performance indices $\left(\emptyset^{\prime}\right)$ in Dutch bay for these bivalve species are slightly higher than those in the Puttalam lagoon (Table 1). This is also possibly die to more favourable environmental conditions in Duch bay than in the lagoos.

In Puttalam lagoon, recruitment patterns of the three bivalve species showed tivo peaks where as in Dutch bay, there was only a single peak (Figs 4 and 5). Relatively stable environmental conditions in Dutch bay compared to those in Puttalam lagoon would have brought about these differences too. Prolific breeding which reflects 1 ecruitment pulses is also a feature of $\mathrm{r}$ selected life styles. As such, the recruitment pulses of these bivalves ia Putalam lagoon are differeırt from highly seasonal recruitment pattern in 


\section{H.M.P. Kithsiri et al.}

Dutch bay, further substantiating the contention that the bivalves in Puttalam lagoon and Dutch bay exhibit r-selected and K-selected life styles respectively.

According to Gulland (1971), the optimum level of exploitation rate (E) in a fishery is 0.5 . If E value is above 0.5 , the fishery is considered to be over-exploited and if it is below 0.5 , fishery is considered to be underexploited. As such, $M$. hiantina and $M$. opima stocks in Dutch bay area appear to be over-exploited and G. tumidum stocks appear to be underexploited. Relative yield per recruit analysis also indicates the same. Fishers usually collect $M$. hiantina and $M$. opima due to their high demand. Further, the relative abundance of these two species was lower than that of $G$. tumidum. Hence over-exploitation of the two main species may have taken place in Dutch Bay.

Relative yield per recruit analysis indicates that to obtain high yield of $M$. hiantina, M. opima in Dutch bay, it is necessary to increase the size at first capture. Yield of G. tumidum could be optimized by increasing $L c$ at a higher level of $\mathrm{E}$.

\section{References}

Amarasinghe, U.S. \& S.S.De Silva 1992.

Population dynamics of Oreochromis mossambicus and $O$. niloticus (Cichlidae) in two reservoirs in Sri Lanka. Asian Fisheries Science 5: 37-61.

Beverton, R.J.H. \& S.J. Holt 1956.

A review of methods for estimating mortality rates in exploited fish populations, with special reference to sources of bias in catch sampling. Rapports et Proces varbaux de Rèunions, Conseil International pour L'Exploration de la Mer 140: 67-83.

Fernando D. H. 1977.

Lamellibranchiate fauna of the estuarine and coastal areas of Sri Lanka. Bulletin of Fisheries Research Station Sri Lanka (Ceylon) 27: 41-50.

Gayanilo, F.C., Jr. \& D.Pauly 1989.

Announcing the release of version 1.1 of the Compleat ELEFAN software package. Fishbyte 7(2): 20-21.

Gayanilo, F.C., Jr., M. Soriano \& D.Pauly 1989.

A Draft Guide to the Compleat ELEFAN. ICLARM Software 2, International Centre for Living Aquatic Resources Management, Manila, Philippines. 67 p. 
Population dynamics of three bivalve species

Gulland, J.A. 1971.

The Fish Resources of the Oceans. Fishing News Books Ltd., Surrey, U.K. 255 p.

Kithsiri, H.M.P., M.J.S. Wijeyaratne and U.S. Amarasinghe 2000.

Influence of some environmental factors on the abundance of three commercially important bivalve species (Family: Veneridae) in the Puttalam lagoon and Dutch bay, Sri Lanka. Sri Lanka Journal of Aquatic Sciences 5: 27-37.

Lovatelli, A. 1988.

Status of mollusc culture in selected Asian countries. Proceedings of the Seventh Session of the IPFC Working Party of Experts on Aquaculture. Indo-Pacific Fisheries Commission, Food and Agriculture Organization of the United Nations, Rome 12: 55-59.

Moreau, J. 1987.

Mathematical and biological expression of growth in fishes: recent trends and further developments. In: Age and Growth of Fish (R.C. Summerfelt \& G.E. Hall eds), pp. 81-113. Iowa State University Press, Iowa.

Oon, N.F. 1986.

Growth and mortality of the Malaysian cockle Anadara granosa under commercial culture. Development of Small-scale Fisheries. Bay of Bengal Programme 47: 1-6.

Pauly, D. \& M.L. Soriano 1986.

Some practical extensions to Beverton and Holt's relative yield-perrecruit model. In: The First Asian Fisheries Forum (J.L. Maclean, L.B. Dizon and L.V. Hosillos eds), pp 491-495. Asian Fisheries Society, Manila, Philippines.

Pianka, E.R. 1970.

On r - and K - selection. American Naturalist 104: 592 - 597. 